\title{
Alleviation of Cold Stress on Tomato During Winter Season by Application of Yeast Extract and Glycinebetaine
}

\author{
E. A. A. Yousef ${ }^{*}$ and M. A. M. Ali** \\ "Department of Horticulture, Faculty of Agriculture, Suez Canal University and \\ ${ }^{* *}$ Department of Horticulture, Faculty of Agriculture, New Valley University, Egypt.
}

\begin{abstract}
$\mathbf{T}$ HE MAIN aim of the current study was to investigate the effect of yeast extract (YE) and glycinebetaine $(\mathrm{GB})$ on mitigation of the low temperature stress in tomato plants cv. Basha $1077 F_{1}$ during the winter season. Sixteen treatments, four YE $(0,3,6$ and $9 \mathrm{~g} / \mathrm{L})$, four GB concentrations $(0,5,10$ and $15 \mathrm{mM})$ and their interaction, were applied and arranged in a randomized complete block design with a split plot arrangement with three replicates. The study results indicated that tomato plants positively responded to the foliar applications of YE and GB. It showed that increasing of foliar application of YE concentrations up to $9 \mathrm{~g} / \mathrm{l}$ increased the vegetative traits (shoot fresh and dry weights, and root fresh and dry weights), yield traits (fruit weight, fruit weight per plant, total yield and marketable yield) and fruit quality traits (total sugars, TSS, vitamin C, carotenoids and lycopene content). Also, foliar application of GB at $5 \mathrm{mM}$ significantly increased the vegetative growth, yield and fruit quality traits compared to the control and other GB treatments. Furthermore, foliar application of YE at $9 \mathrm{~g} / \mathrm{L}$ along with foliar application of GB at $5 \mathrm{mM}$ resulted in the highest values of the above mentioned traits. Moreover, this combination of treatments significantly increased the total chlorophyll content as well as peroxidase and catalase activity. The results of this study suggest use of YE and GB in commercial production of tomato where low temperature is likely.
\end{abstract}

Keywords: Solanum lycopersicum, Cold temperature, Yeast extract, Glycinebetaine.

\section{Introduction}

Climate change is now undeniable and causes harsh environmental stresses for plants. One of the drastic consequences of the climate change is cold temperature during winter. Cold temperature is one of the most critical abiotic types limiting plant growth and productivity causing significant crop losses (Xin \& Browse, 2000 and Lesk et al., 2016). Cold stress-induced injury in plants may appear after 48 to $72 \mathrm{~h}$ of stress exposure (Yadav, 2010). Generally, exposure of plants to extreme waves of cold stress causes severe damage to plant cell membrane, leading to solutes leakages and then cell death (Steponkus, 1984). Also, it causes a significant reduction in net photosynthesis through decreasing the yield of photosystem II (Fv/Fm), efficiency of photosystems I and II (PIABS) as well as content of total chlorophyll a and b (Hajihashemi et al., 2018). In addition, it causes changes in metabolism of the carbohydrates (Frankow-Lindberg, 2001) and causes oxidative stress by increasing the accumulation of reactive oxygen species (ROS) (Dreyer and Dietz, 2018).
There is a solid confirmation that cold stress negatively affects all phases of plant development, including seed germination, vegetative growth, flowering and yield stages through controlling numerous biochemical, molecular and metabolic modifications such as the structure, catalytic properties, function of enzymes and membrane metabolite transporters (Kubien et al., 2003 and Yadav, 2010). Particularly, it decreased the uptake of mineral nutrients, leading to a restriction in the vegetative growth of three passion fruit cultivars (Menzel et al., 1987). Also, it has several major impacts on reproductive organs such controlling flowering time and defects of male and female gametes, which is thought to be one of the main elements accountable for the reduction in yield of crops (Suzuki et al., 2008, Zinn et al., 2010 and Albertos et al., 2019). In addition, it was reported that low temperature adversely reduced grain yield of wheat by $23.8 \%$ to $76.6 \%$ (Liu et al., 2019).

Corresponding author: Eltohamy A.A. Yousef, e-mail:tohamyy@yahoo.com, Tel: 00201028554522

DOI: 10.21608/ejoh.2019.8020.1096

C2019 National Information and Documentation Centre (NIDOC) 
Tomato (Solanum lycopersicum L.) is a common and important vegetable crop over the world due to its nutritional, economical and medicinal values. It is highly sensitive to low temperature (Weiss and Egea-Cortines, 2009). Tomato plants show signs of injury upon exposure to temperature below $10-15^{\circ} \mathrm{C}$ (Guy, 1990). Several aspects of tomato development are negatively affected by cold temperature. For instance, cold temperatures inhibit tomato seed germination (Foolad and Lin, 2000, 2001), disrupt the vegetative growth by defecting the water status and photosynthesis (Venema et al., 2005). In addition, reproductive development in tomato is adversely influenced by low temperature, where it causes a reduction of anther fusion rates by $60 \%$, consequently decreases fruit set (FernandezMunoz et al., 1995 and Lozano et al., 1998). Moreover, mature fruits suffer from chilling injury at temperatures below $12^{\circ} \mathrm{C}$ (Jackman et al., 1988). Thus, the search for tools to regulate tomato growth, development and productivity under cold temperature is important.

When plants encounter a kind of abiotic stresses, they rapidly amassed high concentration of osmo-protectants (Xing and Rajashekar, 2001). Generally, these osmo-protectants are low molecular weight, easily water-soluble compounds that are mostly safe at high cellular concentrations. Among several types of osmoprotectants is glycinebetaine, a quaternary organic compound, which plays an important role in plants under various types of environmental stress, such as high levels of salts and high or low temperature (Sakamoto \& Murata, 2002 and Giri, 2011). Glycinebetaine (GB) protects plants from stress through direct and indirect mechanisms, including stabilizing the structure and efficiency of PS-II, inducing the gene expression, adjustment of cellular osmotic, inhibition of reactive oxygen species, protection of membrane stability, and enhancing antioxidant enzymes activity (Ashraf \& Foolad, 2007 and Chen \& Murata, 2008, 2011). Particular, GB successfully mitigated several kind of biotic stress such waterlogging (Rasheed et al., 2018), cold and chilling (Park et al., 2006 and Karabudak et al., 2014), salinity (Manaf, 2016 and Youssef et al., 2018), high temperature (Li et al., 2011), and drought (Rezaei et al., 2012 and Ragab et al., 2015).

Yeast extract (YE) is a natural source of many growth substances such as vitamins, cytokinins and nutrient elements as well as organic

Egypt. J. Hort. Vol. 46, No.1 (2019) compounds i.e., protein, carbohydrates and lipids (Barnett et al., 1990 and Nagodawithana, 1991). Yeast extract was applied in agricultural sector since long time ago and many helpful effects have been reported such as enhancement of growth and yield (Lonhienne et al., 2014 and Uysal et al., 2014). Yeast extract has been utilized to animate the vegetative growth and yield of potato (El-Tohamy et al., 2015), enhance antioxidant enzyme activity (Maqsood and Abdul, 2017), improve tolerance to abiotic stress such as salinity and drought (Darwesh, 2013, Hammad \& Ali, 2014, Mostafa, 2015 and Nassar et al., 2016), improve nutrient uptake (Hammad and Ali, 2014, Lonhienne et al., 2014) and control postharvest pathogen (Ferraz et al., 2016). It was suggested that yeast extract participate a beneficial role during stress by promotion of the cytokinins content and photosynthetic pigments, crude protein, total phenols, total free amino acids, total carbohydrates and, antioxidant enzyme activity (Barnett et al., 1990, Hammad \& Ali, 2014, Nassar et al., 2016 and Maqsood \& Abdul, 2017).

The present study mainly emphases on investigating the physiological response of tomato plants grown under open field condition in the winter season to foliar applications of yeast, glycinebetaine and their interaction.

\section{Materials and Methods}

\section{Experimental site and plant materials}

Two field experiments were performed at the Agricultural Research Farm of the Faculty of Agriculture, New Valley University, New Valley Governorate, Egypt during the two successive winter seasons of 2016/2017 and 2017/2018. Tomato plants cv. Basha $1077 \mathrm{~F}_{1}$ were used in this study.

\section{Yeast extract and glycinebetain preparation}

The pure dry yeast, Saccharomyces cerevisiae, was obtained from El-Gomhoria Company for chemicals in Egypt. Yeast extract (YE) was prepared according to protocol of Spencer et al. (1983) with some modifications as follow: 0, 3, 6 and 9 gram dry yeast was dissolved in one liter of warm water $\left(35^{\circ} \mathrm{C}\right)$ and then sugar, as source of carbon, was added by $1: 1$. The solutions directly were kept for 24 hours in an incubator $\left(30^{\circ} \mathrm{C}\right)$ to permit the yeast cells multiplication, which helps in production of beneficial carbohydrates, sugars, proteins, amino acids, fatty acids and hormones. Later, the prepared solutions were subjected to one round of freezing for 12 hours and then stored 
in $8^{\circ} \mathrm{C}$ till application. Four concentrations of GB were prepared $(0,5,10$ and $15 \mathrm{mM})$ by dissolving $\mathrm{GB}$ in distilled water.

\section{Experimental design and treatments}

Sixteen treatments, four YE, four GB concentrations and their interactions were applied and arranged in a randomized complete block design (RCBD) with a split plot arrangement with three replicates. The YE concentrations were considered the main plot and the GB levels were considered the subplots. The experimental unit area (plot) was 5 $\mathrm{m} \times 3 \mathrm{~m}$ in size and contained 5 ridges (with $3 \mathrm{~m}$ in length and $1 \mathrm{~m}$ in width for each ridge) and included 30 plants. In both seasons, YE and GB treatments started after 30 days from transplanting date $\left(20^{\text {th }}\right.$ October 2016 and $23^{\text {rd }}$ October 2017) with 15 days intervals. The YE and GB treatments were given to tomato plants 8 times for each through the whole life of the plants on the whole foliage in the morning (9-11 a.m.) with a manual sprayer. Each plot received $0.5-2.5$ liter solution of each treatment according to the age of the plant. The untreated plants were sprayed with only distilled water. For the interaction treatments, the GB treatments were given in the next day for YE treatments.

\section{Soil analysis and metrological data}

Soil texture was sandy, with $\mathrm{pH}$ 8.11, EC $1.09 \mathrm{dS} \mathrm{m}{ }^{-1}$, available $\mathrm{N} 51.3 \mathrm{mg} / \mathrm{kg}$, available P $5.48 \mathrm{mg} / \mathrm{kg}$, available $\mathrm{K} 141.3 \mathrm{mg} / \mathrm{kg}, \mathrm{Ca}^{+2}$ $1.13 \mathrm{meq} / 100 \mathrm{~g}, \quad \mathrm{Mg}^{+2} 0.79 \mathrm{meq} / 100 \mathrm{~g}, \quad \mathrm{Na}^{+}$ $3.37 \mathrm{meq} / 100 \mathrm{~g}, \mathrm{~K}^{+} 0.29 \mathrm{meq} / 100 \mathrm{~g}, \mathrm{HCO}^{3-} 1.29$ $\mathrm{meq} / 100 \mathrm{~g}, \mathrm{Cl}^{-} 3.15 \mathrm{meq} / 100 \mathrm{~g}$ and $\mathrm{SO}_{4}^{-2} 1.14$ meq $/ 100 \mathrm{~g}$ and $\mathrm{CO}_{3}^{-2} 0.00 \mathrm{meq} / 100 \mathrm{~g}$, organic matter $0.55 \%$. These physical and chemical properties of the experimental soil were the average of the two growing seasons and determined according to the methods of Jackson (1973), Chapman and Pratt (1978) and Klute (1986). The meteorological data of the experimental site during the two growing seasons are given in Table 1.

\section{Cultural practices}

After soil clearing and ploughing, $30 \mathrm{~m}^{3}$ organic manure, $350 \mathrm{~kg}$ of calcium superphosphate $(15 \%$ $\mathrm{P}_{2} \mathrm{O}_{5}$ ) and $50 \mathrm{~kg}$ sulpher per fadden were added. Tomato transplants, at 45 days after sowing, were transplanted at $50 \mathrm{~cm}$ apart on one side of ridge. Later, $300 \mathrm{~kg}$ of ammonium nitrate $(33.5 \% \mathrm{~N})$, $200 \mathrm{~kg}$ of potassium sulphate $\left(48 \% \mathrm{~K}_{2} \mathrm{O}\right)$, and 10 $\mathrm{kg}$ magnesium sulphate/fadden were added on four doses. The control of insects and pests were performed according to the instructions of the Egyptian Ministry of Agriculture.

TABLE 1. Monthly meteorological data of the experimental site for New Valley Governorate (El-Kharga station) during the growing seasons.

\begin{tabular}{ccccccc}
\hline \multirow{2}{*}{ Month } & \multicolumn{2}{c}{ Maximum temperature } & \multicolumn{2}{c}{ Minimum temperature } & \multicolumn{2}{c}{ Relative humidity } \\
& \multicolumn{2}{c}{$\left({ }^{\circ} \mathbf{C}\right)$} & & & $\left({ }^{\circ} \mathbf{C}\right)$ & \\
\cline { 2 - 7 } & $\mathbf{2 0 1 7}$ & $\mathbf{2 0 1 8}$ & $\mathbf{2 0 1 7}$ & $\mathbf{2 0 1 8}$ & $\mathbf{2 0 1 7}$ & $\mathbf{2 0 1 8}$ \\
\hline November & 30.0 & 27.5 & 16.0 & 12.9 & 40.3 & 44.0 \\
December & 22.0 & 24.8 & 8.7 & 11.9 & 51.0 & 46.3 \\
January & 21.9 & 22.2 & 6.9 & 6.4 & 48.0 & 49.3 \\
February & 24.5 & 28.8 & 7.3 & 11.8 & 44.3 & 40.0 \\
March & 27.4 & 34.0 & 11.1 & 14.7 & 40.0 & 29.6 \\
April & 34.1 & 35.6 & 18.0 & 17.7 & 29.0 & 26.0 \\
\hline
\end{tabular}

\section{Data recorded}

The following data were recorded during the plant growth and at the harvesting time (April) in both seasons.

\section{Vegetative growth traits}

After 75 days from transplanting, five plants were randomly selected from each experimental unit to estimate the following vegetative traits: shoot fresh and dry weights, and root fresh and dry weights.

Yield traits

At the harvesting time, the fruits of each plot were harvested and the following data were recorded: number of fruit per plant, fruit weight, fruit weight per plant, marketable yield/fadden, and total yield/fadden.

Egypt. J. Hort. Vol. 46, No. 1 (2019 


\section{Quality traits}

At the maturity stage (April) in both seasons, ten mature fruits per experimental unit were selected and used to measure of the following data:

- Total sugars content: It was determined according to methods of Sadasivam and Manickam (1992).

- Total soluble solids (TSS): It was measured according to the method described by A.O.A.C. (1975).

- Ascorbic acid: It was determined by titration with 2.6 diclorophenol indophenol blue dye according to the method reported in A.O.A.C. (1975).

- Lycopene content: It was measured according to according to the method described by Ranganna (1977).

- Carotenoid content: It was measured according as described by Wellburn (1994).

\section{Biochemical analyses}

The following biochemical analyses were assessed in the full expanded fifth leaf from the top of the plants at the age of 75 days after transplanting. Three samples were collected from each experimental unit to record:

- Total chlorophyll content: it was assessed according to Lichtenhaler and Wellburn (1983).

- Proline content: It was measured using a ninhydrin colorimetric method (Bates et al., 1973)

- Peroxidase activity: It was measured estimated according to Osswaldi et al. (1992).

- Catalase activity: It was analyzed as described by Osswaldi et al. (1992).

\section{Statistical analysis}

All statistical analyses of the recorded data were performed using R 3.5.1 software (R, 2013). The analysis of variance was performed and subjected to two-way analysis of variance by a completely randomized design statistical model. Mean values among treatments were compared by Duncn's tests at the 5\% level of significance as implemented in agricolae $\mathrm{R}$ package (de Mendiburu and de Mendiburu, 2017).

\section{Results}

Effect of foliar application of $Y E$ and $G B$ on growth parameters
Results presented in Table 2 represent the effect of YE and GB and their interaction on fresh weight of shoot and root as well as dry weight of shoot and root of tomato plants. It is evident that both YE and GB significantly enhanced growth parameters as compared to the control (untreated plants). Foliar applications of YE showed significant increments in all growth parameters compared to the control plants. However, the plants treated with YE at $9 \mathrm{~g} / \mathrm{l}$ have achieved the highest significant values for all studies traits. Also, Table 2 generally shows that foliar application of GB increased the vegetative growth traits above the control. It also shows that there were significant differences among GB treatments, where the treatment of GB at $5 \mathrm{mM}$ recorded the highest value of vegetative growth and it was followed by $10 \mathrm{mM}$ and $15 \mathrm{mM}$, respectively, in both seasons. It is clear that foliar application of YE at $9 \mathrm{~g} / \mathrm{L}$ with $5 \mathrm{mM}$ GB achieved maximum fresh and dry weights of shoot and root above the rest of treatments.

\section{Effect of foliar application of $Y E$ and $G B$ on yield parameters}

Data illustrated in Table 3 display the effect of $\mathrm{YE}$ and $\mathrm{GB}$ and their interaction on yield parameters. It is evident that both YE and GB treatments led to significant increments in all yield parameters except number of fruits per plant. The general inclination of the all yield parameters except number of fruits was to increase with increasing YE concentration (Table 3). However, the maximum values of mean fruit weight, yield per plant, marketable yield and total yield per feddan were recorded in plants treated with by $\mathrm{YE}$ at $9 \mathrm{~g} / \mathrm{L}$ in both seasons. Also, GB treated plants achieved high values of all yield parameters except number of fruits per/plant compared to the control plants. The GB treated plants at $5 \mathrm{mM}$ gave the maximum values of mean fruit weight, yield per plant, marketable yield and total yield per feddan in both seasons compared to the control and other GB treatments. Meanwhile, there was no significant difference between the GB treatments at 5 and $10 \mathrm{mM}$ in both seasons. Table 3 also shows that the treated plants by $\mathrm{YE}$ at $9 \mathrm{~g} / \mathrm{L}$ and $\mathrm{GB}$ at $5 \mathrm{mM}$ recorded the maximum values for mean fruit weight, yield/ plant, marketable yield/feddan and total yield/ 


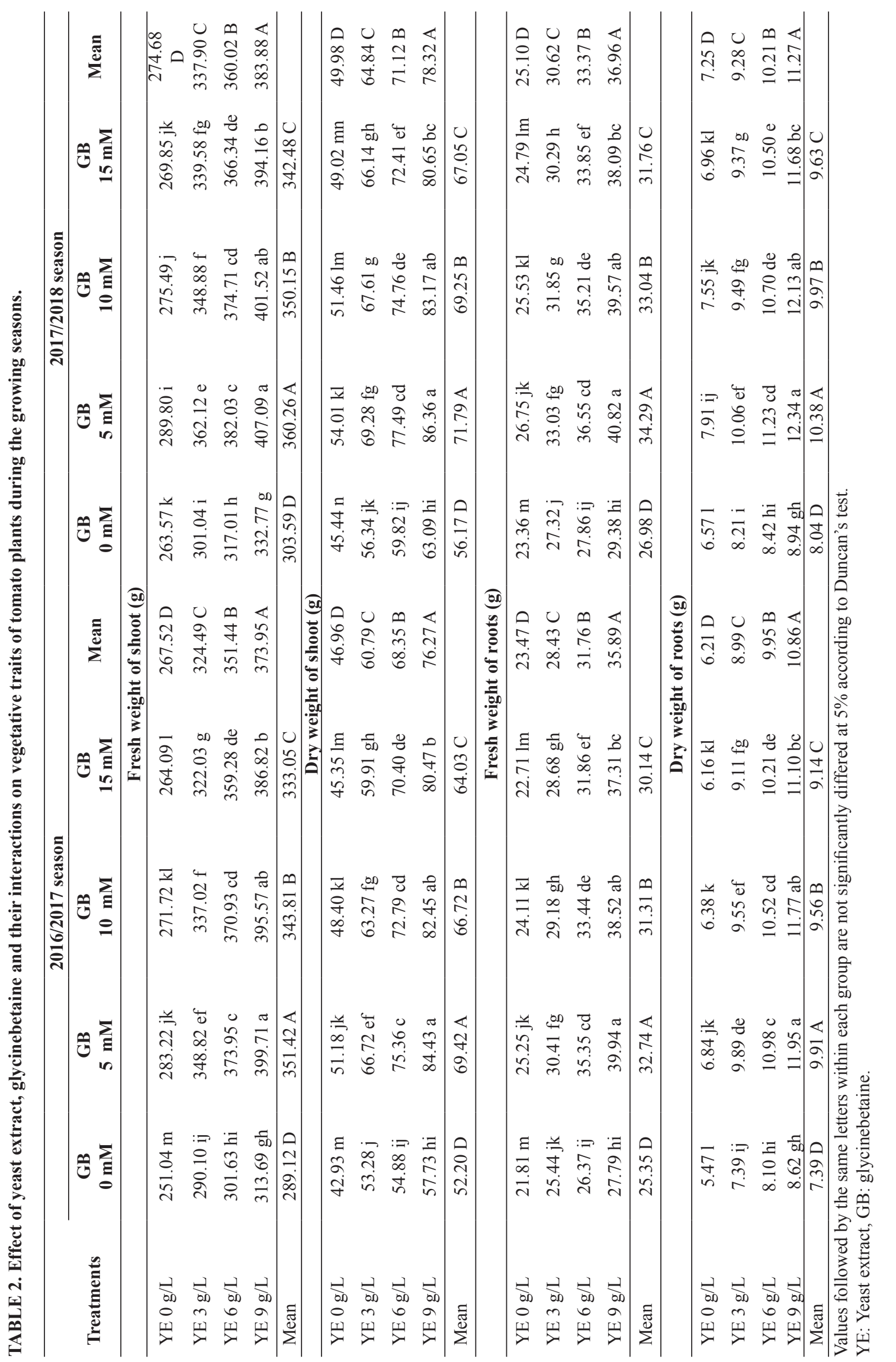

Egypt. J. Hort. Vol. 46, No. 1 (2019 


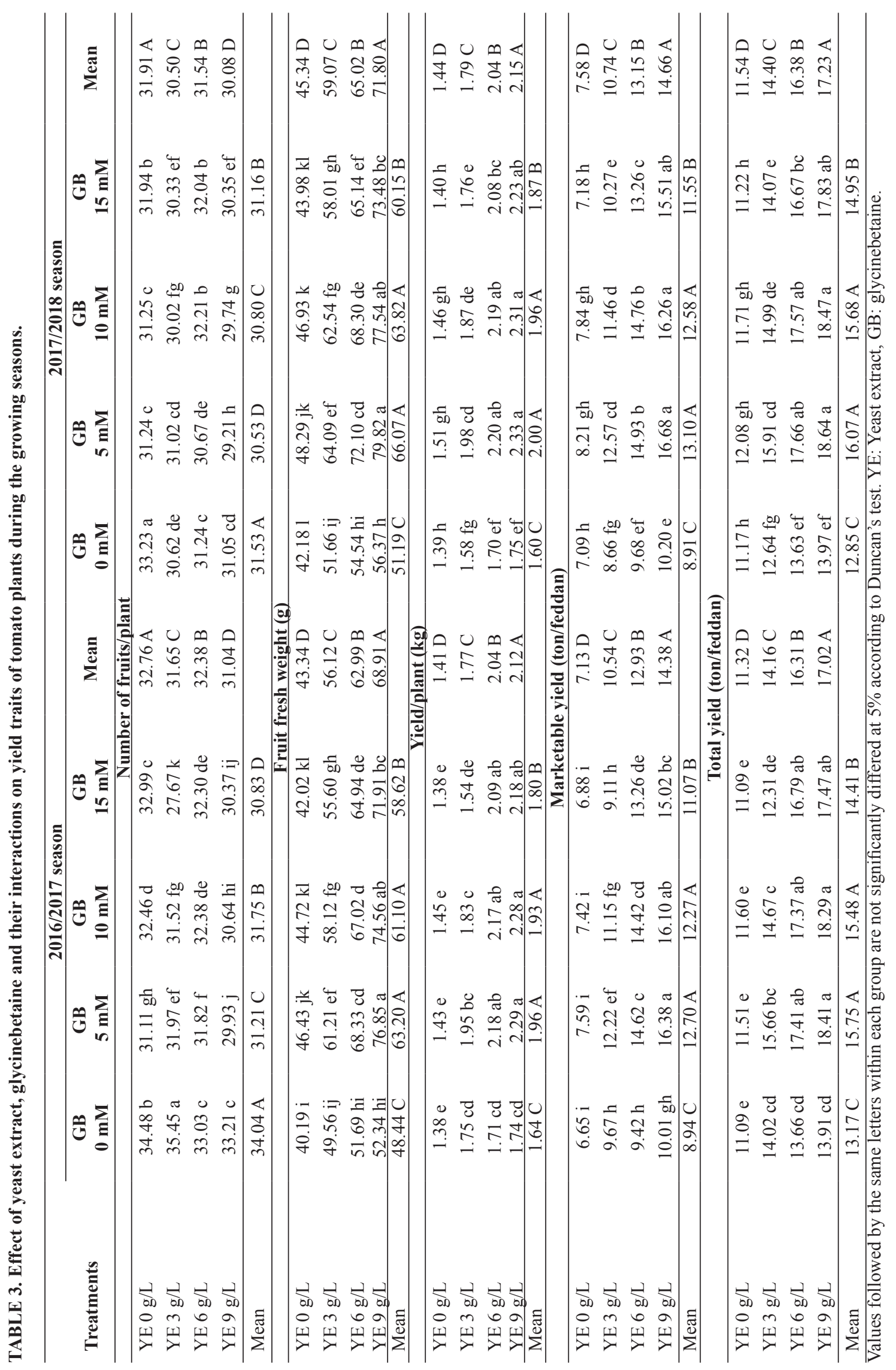

Egypt. J. Hort. Vol. 46, No.1 (2019) 
feddan $(76.85 \mathrm{~g}, 2.29 \mathrm{Kg}, 16.38$ ton/feddan and 18.41 ton/feddan, respectively) in the first season.

\section{Effect of foliar application of YE and GB on fruit quality parameters}

Data represented in Table 4 show the effect of foliar applications of YE, GB and their interaction on fruit quality parameters. It shows that the foliar application of YE and GB improved all quality parameters in the tomato fruits in both seasons. Data indicated that application of YE at 3,6 and $9 \mathrm{~g} / \mathrm{L}$ recorded significant increases in content of total sugars, TSS, vitamin C, carotenoids and lycopene. However, the highest increment in these traits was recorded with treatment of YE at $9 \mathrm{~g} / \mathrm{L}$ in both seasons. As for YE application, it is clear that GB supplementation improved all fruit quality parameters in $1^{\text {st }}$ and $2^{\text {nd }}$ seasons. Meanwhile, there were no significant differences among GB treatments for all fruit quality parameters in both seasons except vitamin $\mathrm{C}$ and lycopene content in season 2017 and 2018, respectively. Regarding the interaction between YE and GB, Table 4 shows that this interaction was significant. It is clear that applications of $\mathrm{YE}$ at $9 \mathrm{~g} / \mathrm{L}$ along with $\mathrm{GB}$ at $5 \mathrm{mM}$ in both seasons led to a significant increases in content of total sugars, TSS, vitamin $\mathrm{C}$, carotenoids and lycopene in the first season (58.89\%, $21.40 \%, 8.65 \%, 48.88 \%$ and $32.04 \%$, respectively) than the control plants, and also in the $2^{\text {nd }}$ season the same trend was observed.

\section{Effect of foliar application of $Y E$ and $G B$ on biochemical constituents}

The effect of exogenous applications of $\mathrm{YE}$ and GB individually or in interaction on biochemical constitutes of fifth leaf of tomato is presented in Table 5. It shows generally that all biochemical studied constitutes were significantly increased at all YE treatments than the control plants except proline. Where, the treatment of YE at $9 \mathrm{~g} / \mathrm{L}$ followed by $\mathrm{YE}$ at $6 \mathrm{~g} / \mathrm{L}$ had recorded the lowest significant of proline content and highest significant of total chlorophyll content, peroxidase and catalase activity (Table 5). In the same regard, GB treatments also improved all biochemical studied constitutes except proline content. However, not all GB treatments have increased significantly the studied biochemical constitutes than the control plants. Obviously, it could be observed that only plants treated with $5 \mathrm{mM}$ GB have the highest significant total chlorophyll content as well as peroxidase and catalase activity as compared with the other GB treatments but they have the lowest proline content (Table 5). The highest significant content of total chlorophyll, peroxidase and catalase activity were recorded with plants treated with $\mathrm{YE}$ at $9 \mathrm{~g} / \mathrm{L}$ and $\mathrm{GB}$ at $5 \mathrm{mM}$, but this combination of YE and GB had the lowest proline content in both seasons.

\section{Discussion}

Worldwide, tomato is one of the most popular and economically significant vegetable crops. Egypt is ranked fifth in worldwide tomato production, with an annual production of 7 , 297,108 tons from around 182,444 hectares (FAO, 2017). Like other plants, temperature profoundly influences the metabolism of tomato plant and thus is a key factor determining the growing season and geographical distribution of tomato (Chinnusamy et al., 2010) Unfortunately, tomato is highly sensitive to low temperature, which is expected to be increased in near future as a consequence of climate change, and shows symptoms of injury upon exposure to low temperature $10-15^{\circ} \mathrm{C}$ (Guy, 1990, Hopkins, 1999 and Weiss \& Egea-Cortines, 2009). Thus, the aim of the current study was to investigate the potential of YE and GB, as an environmentally safe, non-toxic and cost-effective, in alleviation or at least decreasing the harmful effect of low temperature on vegetative growth, yield and fruit quality of tomato plants grown under the open field condition during the winter season.

The current study generally showed that foliar application of YE and GB increased vegetative growth, yield and fruit quality parameters of tomato cv. Basha $1077 \mathrm{~F}_{1}$ grown at low temperature during the winter season. When the YE and GB were foliarly applied on tomato, all growth, yield and fruit quality parameters were enhanced except number of fruit per plant (Tables 2, 3 and 4). For instance, the total yield increased by $66 \%$ and $66.8 \%$ when the plants treated with YE at $9 \mathrm{~g} / \mathrm{L}$ and $\mathrm{GB}$ at $5 \mathrm{mM}$ compared to the untreated plants (Table 3 ) in $1^{\text {st }}$ and $2^{\text {nd }}$ seasons, respectively. In this respect, the YE exogenously applied increased the development and yield of some plant species subjected to abiotic stress such as salinity and drought (Hammad and Ali, 2014, Mostafa, 2015, Nassar et al., 2016). Moreover, fruit yield of tomato was increased by $29-39 \%$ under heat and salt stress when GB was applied during the mid-flowering stage (Mäkelä et al., 1998). Also, GB enhanced the growth and developments of tomato plants grown under waterlogging, high temperature and 


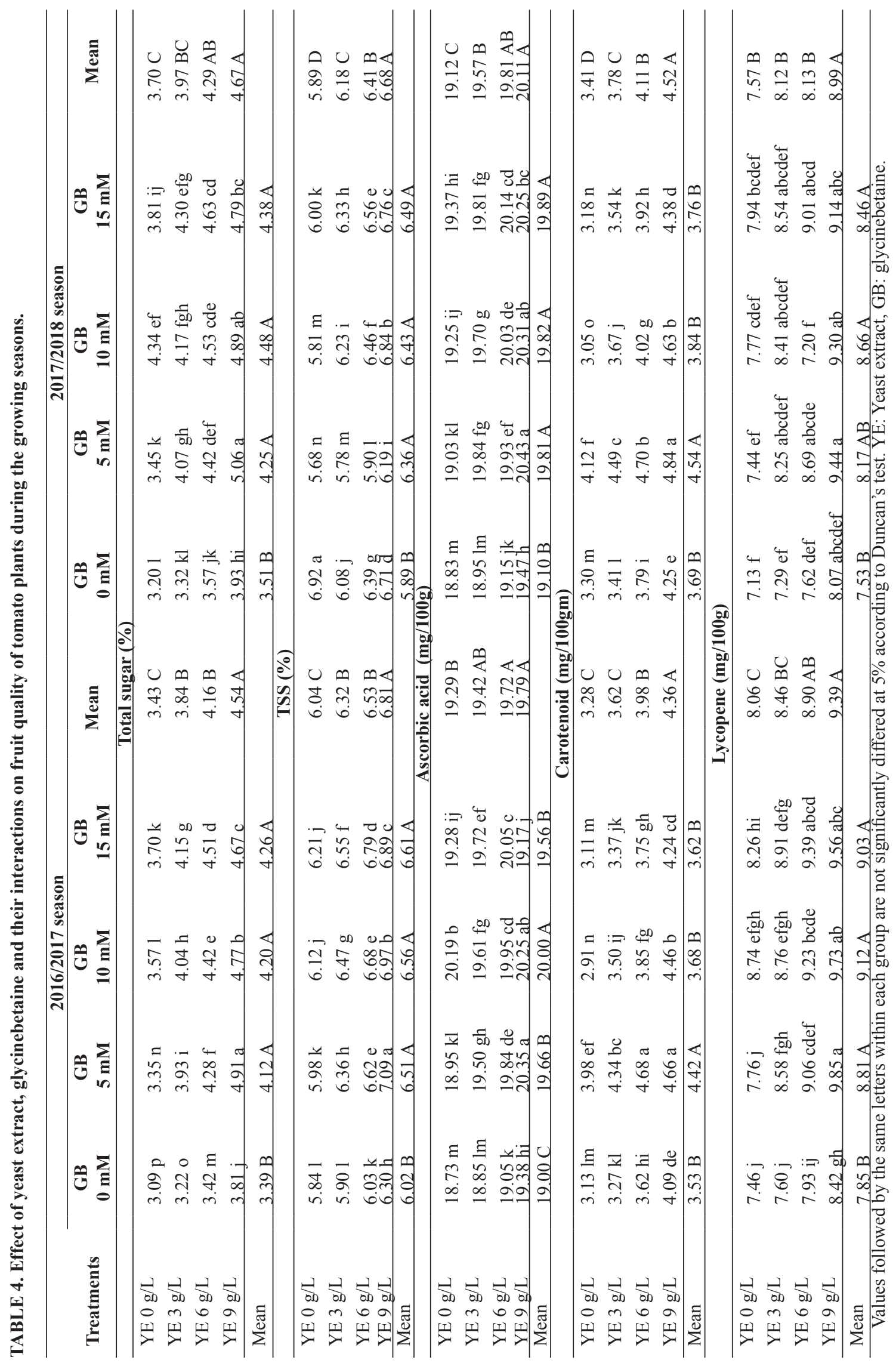

Egypt. J. Hort. Vol. 46, No.1 (2019) 


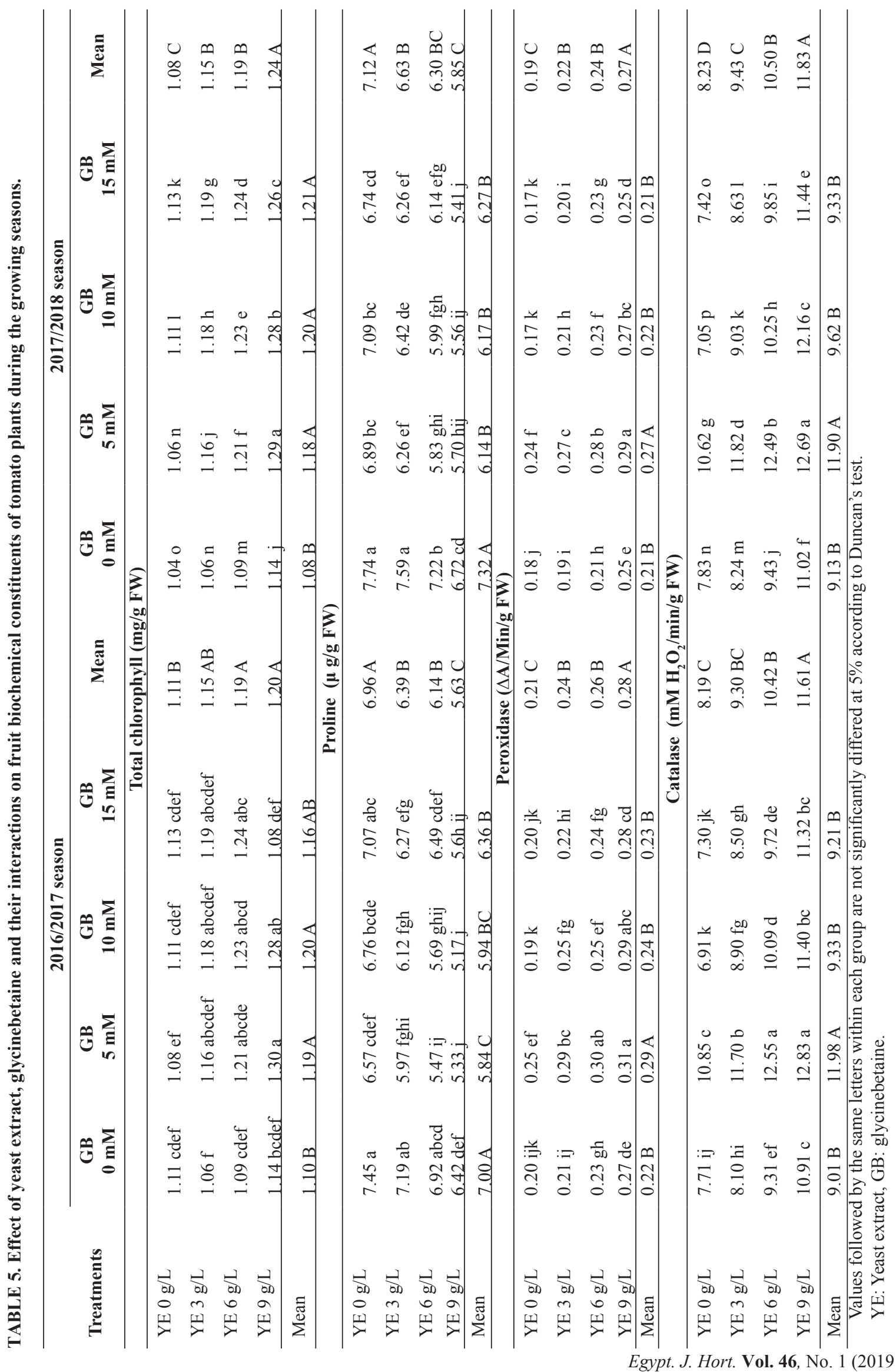


drought stress (Li et al., 2011, Rezaei et al., 2012 and Rasheed et al., 2018), leading to improvement of plant growth and development.

It was previously reported that cold stress caused a significant reduction in photosystem II efficiency (Kalisz et al., 2016, Hajihashemi et al., 2018). Results here showed that the advantageous impact of YE and GB in tomato plants subjected to low temperature, where supplying with YE at $9 \mathrm{~g} / \mathrm{L}$ plus $\mathrm{GB}$ at $5 \mathrm{mM}$ enhanced the total chlorophyll content by $17 \%$ and $24 \%$ in $1^{\text {st }}$ and $2^{\text {nd }}$ season, respectively, compared to the untreated tomato plants (Table 5), consequently altered their vegetative growth and productivity in both seasons. Similar results on increased net chlorophyll content in response to YE application have been stated with stressed leucaena (Nassar et al., 2016), wheat (Hammad and Ali, 2014). Also, GB treatment alleviated the inhibitory effects of waterlogging and cold stress on photosynthetic efficiency, chlorophyll content as well as ratio of maximum florescence induction and variable fluorescence (Fv/Fm) in tomato plants (Karabudak et al., 2014 and Rasheed et al., 2018). Therefore, the increase in the yield of tomato here might be attributed to increased photosynthetic pigment.

To minimize the oxidative damage resulting from abiotic stresses such as cold stress, plants have evolved several enzymatic defense mechanisms to detoxify free radicals and reduce the oxidative stress. Changes of antioxidant enzyme activities are generally correlated with cold stress responses (Nourredine et al., 2015). When plants encounter abiotic stress such as low temperature, they rabidly increase the antioxidant enzymes: catalase and peroxidase in order to collect and prevent $\mathrm{H}_{2} \mathrm{O}_{2}$ from damaging the plant cell. Data recorded in Table 5 clearly indicates that the application of YE and GB significantly improves activity of peroxidase and catalase in tomato leaves during the exposure to low temperature of winter season and the highest mean values of peroxidase and catalase activity were recorded in plants treated with yeast at $9 \mathrm{~g} / \mathrm{L}$ and $\mathrm{GB}$ at $5 \mathrm{mM}$ as compared with control and other treatments in both seasons. These results are in accordance with previous findings in several plant species (Park et al., 2006, Hammad \& ali, 2014, Malekzadeh, 2015 and Rasheed et al., 2018). They found the activity of antioxidant enzymes (eg. peroxidase, catalase, superoxide dismutase) was increased in response to the exogenous supplementation of YE and GB

Egypt. J. Hort. Vol. 46, No.1 (2019) in the leaves of wheat, tomato and soybean plants exposed to drought, waterlogging and salinity stress. The high content of total chlorophyll and high activity of peroxidase and catalase indicate that the YE and GB had an important role in induction of low temperature tolerance in tomato plants grown under low temperature during winter season compared to control plants. Therefore, the explanation to the vegetative and yield increases of the stressed tomato plants in present experiment after application of YE and GB might lie partly on the increased total chlorophyll content and antioxidant activity.

The accumulation of soluble proline in leaves of many higher plant species could be induced by environmental stresses such as light, temperature, drought and salinity. Proline is taught to play a key role in stabilizing subcellular structures (e.g. membranes and proteins), scavenging free radicals, and buffering cellular redox potential under stress conditions (Iqbal, 2009). Our experiment clearly shows that the all YE and GB treatments had achieved a reduction in free proline concentration in leaves of tomato (Table 5). The highest reduction in proline content was recorded in the plants treated with $\mathrm{YE}$ at $9 \mathrm{~g} / \mathrm{L}$ and $\mathrm{GB}$ at 5 $\mathrm{mM}$ (Table 5). In this concern, it was stated that YE and GB treatments significantly improved the decrease of proline content in leaves of wheat, cowpea and alfalfa subjected to water deficit stress (Hammad \& Ali, 2014 and Khadouri, 2015). The low proline content in tomato leaves treated with YE and GB ( $9 \mathrm{~g} / \mathrm{L}$ and $5 \mathrm{mM}$, respectively) may indicate that the treated tomato plants is not so stressed as the control plants. This result refers that the YE and GB have a vital role in induction of low temperature tolerance in tomato plants.

It is realized from result of our experiment that all morphological, yield and fruit quality and biochemical traits with exception of number of fruit per plant and proline content were significantly increased with increasing the YE concentration. Where, the treatment of YE at 9 $\mathrm{g} / \mathrm{L}$ had recorded the highest values for mostly of the studied traits (Tables 2, 3, 4 and 5). In the same regard, Hammad and Ali (2014) found that treatment of YE at $6 \mathrm{~g} / \mathrm{L}$ was more effective than the $\mathrm{YE}$ at $3 \mathrm{~g} / \mathrm{L}$ in terms of improved drought tolerance. A possible explanation for such promotional effect of $\mathrm{YE}$ at $9 \mathrm{~g} / \mathrm{L}$ is that $\mathrm{YE}$ is a rich source for vitamins, cytokinins, nutrient elements and organic compounds i.e., protein, 
carbohydrates, nucleic acid and lipids (Barnett et al., 1990 and Nagodawithana, 1991). Therefore, $9 \mathrm{~g} / \mathrm{L}$ had more beneficial substances more than the other treatments ( 3 and $6 \mathrm{~g} / \mathrm{L}$ ), resulting in high vegetative growth and yield and fruit quality. On the contrary, the low assigned concentration of GB $(5 \mathrm{mM})$ had the most significantly positive effect on vegetative growth, yield, fruit quality and physiological traits except number of fruit per plant and proline content compared to the other GB treatments $(10$ and $15 \mathrm{mM})$ and control plants. The present findings are generally in contrast with those reported by Rezaei et al. (2012) as well as Dawood and Sadak (2014), who reported that the high concentration of GB (10 and $20 \mathrm{mM}$ ) were more effective than the low concentrations in alleviation the harmful effects resulting from drought stress in canola and tomato. However, the weak effect of high concentrations of GB (10 and $15 \mathrm{mM})$ in the present study might be attributed to the deleterious effects of $\mathrm{GB}$, which cause a reduction in osmotic adjustment when is applied in high concentrations through inhibiting the proline and ion accumulation (Heuer, 2003). Taken together, these results indicate that the optimum of GB depends on the plant itself and abiotic stress and should be taken into consideration in further studies.

\section{Conclusion}

Low temperature stress is a harsh constraint, which negatively affect the tomato productivity. However, foliar application of YE and GB may be useful approach in reducing the cold-induced yield losses in tomato. In this study, potential of foliar application of YE and GB in enhancing the performance of tomato against low temperature stress was investigated. Both YE and GB were foliage applied in tomato plants cv. Basha $1077 \mathrm{~F}_{1}$ grown in the open filed during two winter seasons. The foliar application of YE and GB improved the total chlorophyll content as well as activity of peroxidase and catalase, which resulted in better vegetative growth under low temperature, thus resulting in better total yield and marketable yield per feddan. However, foliage applied YE at $9 \mathrm{~g} / \mathrm{L}$, and $\mathrm{GB}$ at $5 \mathrm{mM}$ was most effective than the other concentrations of these stimulators.

\section{Acknowledgment}

We express our thanks to Prof. Dr. Samir ElSeifi for proofreading of the earlier version of the manuscript.

\section{Funding statement}

We express our appreciation to the Horticulture Department, Faculty of Agriculture, Suez Canal University for supplying the chemicals for this research work.

\section{Conflict of interest}

The authors declare that they have no conflict of interest.

\section{References}

A.O.A.C. (1975) Official Methods of Analysis, $12^{\text {th }}$ ed., Association of Official Analytical Chemists, Washington DC.

Albertos, P. and Wagner, K., Poppenberger, B. (2019) Cold stress signalling in female reproductive tissues. Plant Cell Environ., 42 (3), 846-853.

Ashraf, M. and Foolad, M. (2007) Roles of glycine betaine and proline in improving plant abiotic stress resistance. Environ. Exp. Bot., 59 (2), 206-216.

Barnett, J.A., Payne, R.W. and Yarrow, D. (1990) Yeast Characteristics and Identification, $2^{\text {nd }} \mathrm{ed.}$ Press, Cambridge Univ., London, UK, 1012 pp.

Bates, L.S., Waldren, R.P. and Teare, I.D. (1973) Rapid determination of free proline for water-stress studies. Plant soil., 39 (1), 205-207.

Chapman, H.D. and Pratt, P.F. (1978) Methods of Analysis for Soils, Plants and Water. Division of Agriculture Sciences, University of California, Davis, pp. 162-165.

Chen, T.H. and Murata, N. (2008) Glycinebetaine: an effective protectant against abiotic stress in plants. Trends Plant Sci., 13 (9), 499-505.

Chen, T.H. and Murata, N. (2011) Glycinebetaine protects plants against abiotic stress: mechanisms and biotechnological applications. Plant Cell Environ., 34 (1), 1-20.

Chinnusamy, V., Zhu, J.K. and Sunkar, R. (2010) Gene regulation during cold stress acclimation in plants. In: Sunkar, R. (Eds.), Plant Stress Tolerance. Humana Press, New York, pp. 39-55.

Dawood, M.G. and Sadak, M.S. (2014) Physiological role of glycinebetaine in alleviating the deleterious effects of drought stress on canola plants (Brassica napus L.). Middle East J. Agric. Res., 3 (4), 943-954.

Darwesh, R.S. (2013) Improving growth of date palm plantlets grown under salt stress with yeast and amino acids applications. Ann. Agric. Crop Sci., 58 (2), 247-256. 
Dreyer, A. and Dietz, K.J. (2018) Reactive Oxygen Species and the Redox-Regulatory Network in Cold Stress Acclimation. Antioxidants, 7 (11), 169.

El-Tohamy, W.A., El-Abagy, H.M., Badr, M.A., AbouHussein, S.D., Helmy, Y.I. and Shafeek, M.R. (2015) Effects of yeast extract and GA3 on water status, growth, productivity and quality of sweet potato grown in sandy soils. Int. J. Environ., 4 (4), 256-261

de Mendiburu, F. and de Mendiburu, M.F. (2017) Package 'agricolae'. R Package, Version, 1-2.

FAO (Food and Agriculture Organization of the United Nations), (2017) Retrieved January 2018 from the FAOSTAT on the world Wide. http://www.fao.org/ faostat/en/\#data/QC

Fernandez-Munoz, R., Gonzalez-Fernandez, J.J. and Cuartero, J. (1995) Variability of pollen tolerance to low temperatures in tomato and related wild species. J. Am. Soc. Hortic. Sci., 70 (1), 41-49.

Ferraz, L.P., da Cunha, T., da Silva, A. C. and Kupper, K.C. (2016) Biocontrol ability and putative mode of action of yeasts against Geotrichum citri-aurantii in citrus fruit. Microbiol. Res., 188, 72-79.

Foolad, M.R. and Lin, G.Y. (2000) Relationship between cold tolerance during seed germination and vegetative growth in tomato: germplasm evaluation. J. Am. Soc. Hortic. Sci., 125 (6), 679-683.

Foolad, M.R. and Lin, G.Y. (2001) Genetic analysis of cold tolerance during vegetative growth in tomato, Lycopersicon esculentum Mill. Euphytica, 122 (1), 105-111.

Frankow-Lindberg, B.E. (2001) Adaptation to winter stress in nine white clover populations: changes in non-structural carbohydrates during exposure to simulated winter conditions and 'spring' regrowth potential. Ann. Bot., 88 (1), 745-751.

Giri, J. (2011) Glycinebetaine and abiotic stress tolerance in plants. Plant Signal. Behav., 6 (11), 1746-1751.

Guy, C.L. (1990) Cold acclimation and freezing stress tolerance: role of protein metabolism. Annu. Rev. Plant Biol., 41 (1), 187-223.

Hammad, S.A. and Ali, O.A. (2014) Physiological and biochemical studies on drought tolerance of wheat plants by application of amino acids and yeast extract. Ann. Agric. Sci., 59 (1), 133-145.
Hajihashemi, S., Noedoost, F., Geuns, J.M., Djalovic, I. and Siddique, K.H. (2018) Effect of Cold Stress on Photosynthetic Traits, Carbohydrates, Morphology, and Anatomy in Nine Cultivars of Stevia rebaudiana. Front. Plant Sci., https://doi. org/10.3389/fpls.2018.01430

Heuer, B. (2003) Influence of exogenous application of proline and glycinebetaine on growth of saltstressed tomato plants. Plant Sci., 165 (4), 693-699.

Hopkins, W.G. (1999) Introduction to Plant Physiology. $2^{\text {nd }}$ ed. John Wiley, New York, 560 p.

Iqbal, S. Physiology of Wheat (Triticum aestivum L.) Accessions and the Role of Phytohormones Under Water Stress. Ph.D. Thesis, Quaid-i-azam Univ., Islamabad, 2009.

Jackman, R.L., Yada, R.Y., Marangoni, A., Parkin, K.L. and Stanley, D.W. (1988) Chilling injury. A review of quality aspects. J. Food. Qual., 11 (4), 253-278.

Jackson, M.L. (1973) Soil Chemical Analysis. Prentice Hall of India Ltd, New Delhi, India, 498 pp.

Kalisz, A., Jezdinský, A., Pokluda, R., Sękara, A., Grabowska, A. and Gil, J. (2016) Impacts of chilling on photosynthesis and chlorophyll pigment content in juvenile basil cultivars. Hortic. Environ. Biotechnol., 57(4), 330-339.

Karabudak, T., Bor, M., Özdemir, F. and Türkan, I. (2014) Glycine betaine protects tomato (Solanum lycopersicum) plants at low temperature by inducing fatty acid desaturase 7 and lipoxygenase gene expression. Molecular Biology Reports, 41 (3), 1401-1410.

Khadouri, H. K. Effects of Glycine Betaine on Plant Growth and Performance of Alfalfa (Medicago Sativa L.) \& Cowpea (Vigna Unguiculata L. Walp.) Within Water Deficit Conditions. M.Sc. Thesis, United Arab Emirates Univ., Alin, 2015.

Klute, A. (1986) Methods of Soil Analysis, $2^{\text {nd }}$ ed. American Society of Agronomy, Madison, Wisconsin, $183 \mathrm{p}$.

Kubien, D.S., von Caemmerer, S., Furbank, R.T. and Sage, R.F. (2003) C4 photosynthesis at low temperature. A study using transgenic plants with reduced amounts of Rubisco. Plant Physiol., 132 (3), 1577-1585.

Lesk, C., Rowhani, P. and Ramankutty, N. (2016) Influence of extreme weather disasters on global crop production. Nature, 529, 84-87. 
Li, S., Li, F., Wang, J., Zhang, W.E.N., Meng, Q., Chen, T.H. and Yang, X. (2011) Glycinebetaine enhances the tolerance of tomato plants to high temperature during germination of seeds and growth of seedlings. Plant Cell Environ., 34(11), 1931-1943.

Lichtenhaler, H.K. and Wellburn, A.R. (1983) Determinations of total carotenoids and chlorophylls a and b of leaf extracts in different solvents. Biol. Soc. Trans., 11, 591-592.

Liu, L., Ji, H., An, J., Shi, K., Ma, J., Liu, B. and Zhu, Y. (2019) Response of biomass accumulation in wheat to low-temperature stress at jointing and booting stages. Environ. Exp. Bot., 157, 46-57.

Lonhienne, T., Mason, M.G., Ragan, M.A., Hugenholtz, P., Schmidt, S. and Paungfoo-Lonhienne, C. (2014). Yeast as a biofertilizer alters plant growth and morphology. Crop Sci., 54 (2), 785-790.

Lozano, R., Angosto, T., Gómez, P., Payán, C., Capel, J., Huijser, P. and Martınez-Zapater, J.M. (1998) Tomato flower abnormalities induced by low temperatures are associated with changes of expression of MADS-box genes. Plant Physiol., 117 (1), 91-100.

Malekzadeh, P. (2015) Influence of exogenous application of glycinebetaine on antioxidative system and growth of salt-stressed soybean seedlings (Glycine max L.). Physiol. Mol. Biol. Plants, 21 (2), 225-232.

Mäkelä, P., Jokinen, K., Kontturi, M., Peltonen-Sainio, P., Pehu, E. and Somersalo, S. (1998) Foliar application of glycinebetaine-a novel product from sugar beet-as an approach to increase tomato yield. Ind. Crops Prod., 7 (2-3), 139-148.

Manaf, H.H. (2016) Beneficial effects of exogenous selenium, glycine betaine and seaweed extract on salt stressed cowpea plant. Ann. Agric. Sci., 61 (1), $41-48$.

Maqsood, M. and Abdul, M. (2017) Yeast extract elicitation increases vinblastine and vincristine yield in protoplast derived tissues and plantlets in Catharanthus roseus. Rev. Bras. Farmacogn., 27 (5), 549-556.

Menzel, C.M., Simpson, D.R. and Winks, C.W. (1987) Effect of temperature on growth, flowering and nutrient uptake of three passion fruit cultivars under low irradiance. Sci. Hortic., 31 (3-4), 259-268.
Mostafa, G.G. (2015) Improving the Growth of Fennel Plant Grown under Salinity Stress using some Biostimulants. Am. J. Plant Physiol., 10 (2), 77-83.

Nagodawithana, W.T. (1991) Yeast Technology. Universal foods corporation Milwaukee, Wisconsin. Van Nostrand Reinhold, NewYork, 273 p.

Nassar, R.M., Shanan, N.T. and Reda, F.M. (2016) Active yeast extract counteracts the harmful effects of salinity stress on the growth of leucaena plant. Sci. Hortic., 201, 61-67.

Nourredine, Y., Naima, A., Dalila, H., Habib, S. and Karim, S. (2015) Changes of peroxidase activities under cold stress in annuals populations of Medicago. Mol. Plant Breed., 6 (5), 1-9.

Osswaldi, W.F., Kraus, R., Hippeli, S., Benz, B., Volpert, R. and Elstner, E.F. (1992) Comparison of the Enzymatic Activities of Dehydroascorbic acid Reductase, Glutathione Reductase, Catalase, Peroxidase and Superoxide Dismutase of Healthy and Damaged Spruce Needles (Picea abies (L.) Karst.)'. J. Plant Physiol.,139 (6), 742-748.

Park, E.J., Jeknic, Z. and Chen, T.H. (2006) Exogenous application of glycinebetaine increases chilling tolerance in tomato plants. Plant Cell Physiol., 47 (6), 706-714.

R Core Team (2017) R: a language and environment for statistical computing. Vienna (Austria): R Foundation for Statistical Computing. Vienna (Austria): URL http://www.R-project.org/.

Ragab, M.E., Helal, N.A., Sawan, O.M., Fawzy, Z.F. and El-Sawy, S.M. (2015) Foliar application of glycine betaine for alleviating water stress of tomato plants grown under sandy soil conditions. Inter. $J$. Chemtec. Tech. Res., 8 (12), 52-67.

Rangana, S. (1977) Manual for analysis of fruit and vegetable products. McGraw Hill, New Delhi, India, $\mathrm{p} 77$.

Rasheed, R., Iqbal, M., Ashraf, M.A., Hussain, I., Shafiq, F., Yousaf, A. and Zaheer, A. (2018) Glycine betaine counteracts the inhibitory effects of waterlogging on growth, photosynthetic pigments, oxidative defence system, nutrient composition, and fruit quality in tomato. J. Hortic. Sci. Biotechnol., 93 (4), 385-391. 
Rezaei, M.A., Jokar, I., Ghorbanli, M., Kaviani, B. and Kharabian-Masouleh, A. (2012) Morphophysiological improving effects of exogenous glycine betaine on tomato (Lycopersicum esculentum Mill.) cv. PS under drought stress conditions. Plants Omics., 5, 79-86.

Sakamoto, A. and Murata, N. (2002) The role of glycine betaine in the protection of plants from stress: clues from transgenic plants. Plant Cell Environ., 25 (2), 163-171.

Sadasivam, S. and Manickam, A. (1992) Biochemical Methods for Agricultural Sciences, Wiley Eatern Limited, New Delhi, India, 246 p.

Steponkus, P.L. (1984) Role of the plasma membrane in freezing injury and cold acclimation. Annu. Rev. Plant Physiol., 35 (1), 543-584.

Spencer, T.F.T., Dorothy S.M. and Smith, A.R.W. (1983) Yeast genetics: fundamental and applied aspects. Springer. Verlag. New York., U.S.A, pp 16- 18.

Suzuki, K., Nagasuga, K. and Okada, M. (2008) The chilling injury induced by high root temperature in the leaves of rice seedlings. Plant Cell Physiol., 49 (3), 433-442.

Uysal, A., Demir, S., Sayilgan, E., Eraslan, F. and Kucukyumuk, Z. (2014) Optimization of struvite fertilizer formation from baker's yeast wastewater: growth and nutrition of maize and tomato plants. Environ. Sci. Pollut. Res., 21 (5), 32643274.

Venema, J.H., Linger, P., Van Heusden, A.W., Van Hasselt, P.R. and Brüggemann, W. (2005) The inheritance of chilling tolerance in tomato (Lycopersicon spp.). Plant Biol., 7 (02), 118-130.
Weiss, J. and Egea-Cortines, M. (2009) Transcriptomic analysis of cold response in tomato fruits identifies dehydrin as a marker of cold stress. J. Appl. Genet., 50 (4), 311-319.

Wellburn, A.R. (1994) The spectral determination of chlorophylls a and b, as well as total carotenoids, using various solvents with spectrophotometers of different resolution. J. Plant Physiol., 144 (3), 307313.

Xin, Z. and Browse, J. (2000) Cold comfort farm: the acclimation of plants to freezing temperatures. Plant Cell Environ., 23 (9), 893-902.

Xing, W. and Rajashekar, C.B. (2001) Glycine betaine involvement in freezing tolerance and water stress in Arabidopsis thaliana. Environ. Exp. Bot., 46 (1), 21-28.

Yadav, S.K. (2010) Cold stress tolerance mechanisms in plants. A review. Agron. Sustain. Dev., 30, 515 527.

Youssef, S.M., Abd Elhady, S.A., Aref, R.M. and Riad, G.S. (2018) Salicylic acid attenuates the adverse effects of salinity on growth and yield and enhances peroxidase isozymes expression more competently than proline and glycine betaine in cucumber plants. Gesunde Pflanzen, 70, 75-90.

Zinn, K.E., Tunc-Ozdemir, M. and Harper, J.F. (2010) Temperature stress and plant sexual reproduction: uncovering the weakest links. J. Exp. Bot., 61(7), 1959-1968.

Received 06/02/2019, accepted 22/03/2019) 


\section{تخفيف إجهاد البرودة على الطماطم خلال فصل الشتاء عن طريث إستخدام مستخلص الخميرة والجليسين بيتّايين إنين

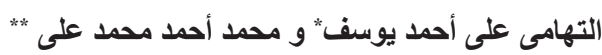

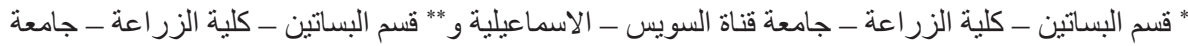

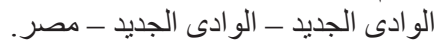

كان الهدف الرئيسي من الدر اسة الحالية هو در اسة تأثثر مستخلص الخميرة و الجليسين بيتايين في تخفيف إجهاد

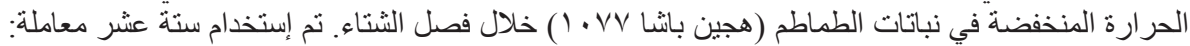

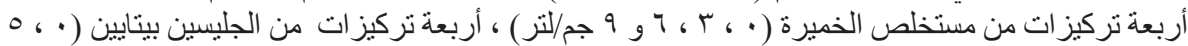

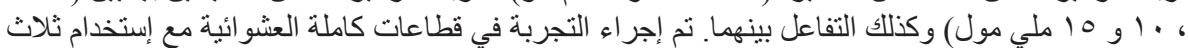

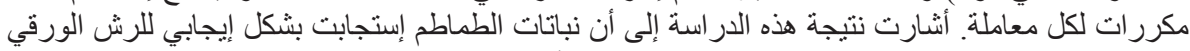

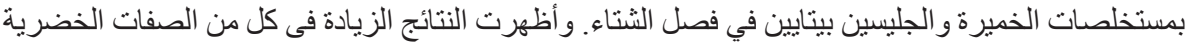

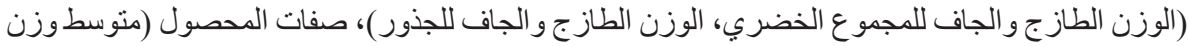

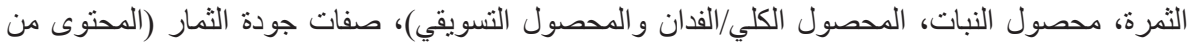

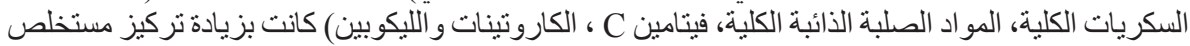

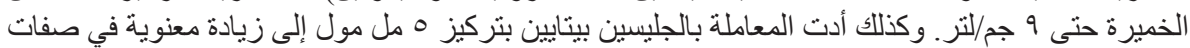

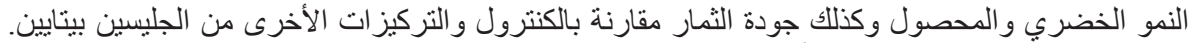

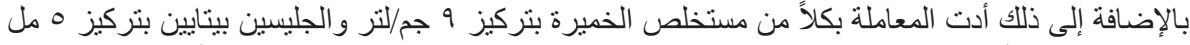

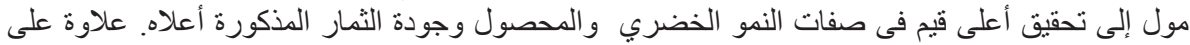

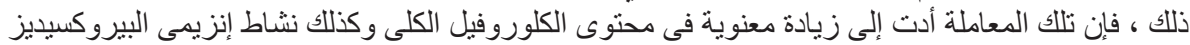

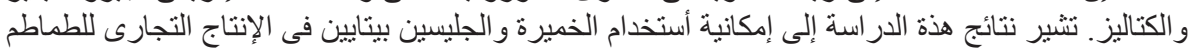
بالمناطق ذات الحر ارة المنخفضة. 